\title{
Foliar Application of Gebbrillic and Salicylic Acids Improves Fruit Quality and Yield and Reduces Aphid Population in Pomegranate (Punica granatum L.) Abd El-all, E. H. ${ }^{1}$ and H. A. Fouad ${ }^{2}$ \\ ${ }^{1}$ Horticulture Department, Faculty of Agriculture, Sohag University, Sohag, Egypt. \\ ${ }^{2}$ Plant Protection Dep., Faculty of Agriculture, Sohag University, Sohag, Egypt.
}

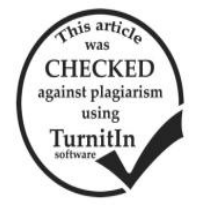

\section{ABSTRACT}

Pomegranate crop suffers many problems during tree growth and fruit production stages. The pomegranate ramp, Aphis punicae (Passerini) is serious pests that attack pomegranate in Egypt. This study was carried out to examine the influence of ascorbic acid (ASA), gibbrellic acid $\left(\mathrm{GA}_{3}\right)$ and salicylic acid (SA) on yield and fruit quality and aphid population in pomegranate. The application rates were $(250,500$ and $1000 \mathrm{ppm})$ for ASA, 250, 500 and $1000 \mathrm{ppm}$ for GA and 200, 400 and $600 \mathrm{ppm}$ for SA thrice during the growing season. The foliar application of $\mathrm{GA}_{3}$ and SA improved yield $(\mathrm{kg} /$ tree), fruit weight $(\mathrm{g})$, fruit number/tree, fruit cracking, TSS, acidity $\%$, TSS/acid \% ratio, and reduced aphid population.

Keywords: Aphis punicae, control, elicitors, fruit quality, pomegranate, yield

\section{INTRODUCTION}

Pomegranate (Punica granatum L.) is an important fruit species that has been widely cultivated in many parts of the world (Sarkhosh et al., 2007; Stover and Mercure, 2007). Recently, pomegranate has drawn attention as a commercial crop because of the benefits of human nutrition provided by these fruits and their derived products associated with high levels of antioxidants in pulp or juice (Davidson et al., 2009). However, pomegranate production suffers many problems during tree growth and fruit production. The most common problems during maturity are the low fruit quality and cracking. In addition, the pomegranate ramp, Aphis punicae (Passerini) (Homoptera: Aphididae) is serious pests that attack pomegranate orchards around the world, including Egypt. It is well known for its ability to reduce plant activity, facilitate the growth of mold on leaves, and reduce the quality and quantity of fruit.

A common practice used in enhancing fruit quality and controlling pest in pomegranate is the application of traditional chemical substances which may have harmful effects and serious consequences on human, animals and environment. The alternative approach to improve the quality of pomegranate fruit and to control pomegranate pests effectively to respond to problems associated with the indiscriminate use of chemical substances has become an urgent necessity. Elicitors such as ascorbic acid (ASA), gibberelic acid $\left(\mathrm{GA}_{3}\right)$ and salicylic acid (SA) are signalling molecules that play an important role in regulating plant growth and improving plant strength under biotic and abiotic stresses (Hayat et al., 2010 and War et al., 2012).

They can play an essential role in controlling the quality of fruits such as colour, flavour, acidity, size and weight (Kondo, 2006; Elwan and El-Hamahmy, 2009; Marzouk and Kassem, 2011). Moreover, aphid feeding may trigger plant signalling pathways driven by salicylic acid (SA), ascorbic acid (ASA) or gibberelic acid $\left(\mathrm{GA}_{3}\right)$, that induce the production of chemical defences (Smith and Boyko, 2007; Goggin, 2007 and Walling, 2008).

These natural elicitors, however, may be produced in plant in low quantities that might not help the plant to overcome the biotic and abiotic stress. Thus, the exogenous applications of these substances enhance plant performance. But no previous study has been conducted on the double effect of these elicitors on improving the fruit quality and reducing the incidence of the aphids on pomegranate orchards. Therefore, the objective of the current study is to investigate the influence of ascorbic acid (ASA), gibberelic acid $\left(\mathrm{GA}_{3}\right)$ and salicylic acid (SA) use to improve fruits quality of pomegranate and reduce aphid population in the pomegranate tree.

\section{MATERIALS AND METHODS}

\section{Field experimental}

The experiment was performed on 19-year-old pomegranate trees (Punica granatumL.), cultivar Manfaloty planted in 5X5 meter in sandy soil in the Experimental Farm at Sohag University (El-Kawther, Sohag, Egypt), during 2017 and 2018 seasons. The experiment was laid out in a randomized complete block design (RCBD) with three replications per treatment. Three levels of ascorbic acid (ASA), gibberelic acid $\left(\mathrm{GA}_{3}\right)$ and salicylic acid (SA) were used. Knapsack hand spray (20 L capacity) fitted with one nozzle was used for spraying the treatments.

Ascorbic acid (ASA), gibberelic acid $\left(\mathrm{GA}_{3}\right)$ and salicylic acid (SA) application

Three rates of each substance were applied thrice in the third week of April, the first week of May and the first week of June. The application rates were 250, 500 and $1000 \mathrm{ppm}$ ) for ASA 250, 500 and $1000 \mathrm{ppm}$ for $\mathrm{GA}_{3}$ and 200, 400 and $600 \mathrm{ppm}$ for SA. Control sprayed with distilled water. Tested trees were received equal amounts of applied solutions. All chemicals were purchased from Sigma-Aldrich Co., Egypt.

\section{Insect counting}

The aphid populations were counted from five terminal branches, including leaves, flowers, and fruits before and after foliar application at periods of 1, 3, 6, 9 and 12 days after first spray only due to the high population levels of the aphid. The reduction percentages of aphids were calculated according to Henderson and Tilton's equation (Henderson and Tilton, 1955).

\section{Statistical analysis}

Data were analysed using one-way ANOVA and presented as mean of values. Means were compared by New LSD Test at $\mathrm{P}<0.05$ level of probability.

\section{RESULTS AND DISCUSSION}

\section{RESULTS}

In general, the application of $\mathrm{ASA}, \mathrm{GA}_{3}$ and SA improved plant growth and fruit quality in pomegranates and reduced aphid population. $\mathrm{GA}_{3}$ surpassed ASA and SA in tested yield and fruit quality traits. There were 
significant differences among all treatments, but the lowest rates of ASA did not differ significantly from control.

1-Yield (kg/tree), fruit weight (g) and fruit number/tree:

Data in Table (1) clearly show that subjecting the trees to $\mathrm{GA}_{3}$ significantly improved yield expressed in terms of fruit weight and number per tree relative to the control. There was a gradual increase in fruit yield, fruit weight and fruit number/tree with increasing concentrations of each material. The maximum yield $(58.90,52.67 \mathrm{~kg} /$ tree $)$ was recorded in trees that sprayed with $\mathrm{GA}_{3}$ at $1000 \mathrm{ppm}$, while, the lowest yield (41.00, $36.67 \mathrm{~kg} /$ tree) was recorded in the untreated trees in both seasons. Similarly, $\mathrm{GA}_{3}$ at $1000 \mathrm{ppm}$ gave the highest values for fruit weight and fruit number /tree in both seasons. Control, on the other hand gave the lowest values in both seasons.

Table 1. Effect of spraying application with ascorbic acid (ASA), gibberelic acid (GA $\mathbf{G}_{3}$ ) and salicylic acid (SA) on yield (kg/tree), fruit number/tree and fruit weight of Manfalouty pomegranate trees during 2016/2017 season.

\begin{tabular}{|c|c|c|c|c|c|c|c|}
\hline \multirow{2}{*}{ Treatments } & \multirow{2}{*}{$\begin{array}{l}\text { Conc. } \\
\text { (ppm) }\end{array}$} & \multicolumn{2}{|c|}{ yield (kg/tree) } & \multicolumn{2}{|c|}{ fruit number/tree } & \multicolumn{2}{|c|}{ fruit weight } \\
\hline & & 2016 & 2017 & 2016 & 2017 & 2016 & 2017 \\
\hline Control & - & 41.00 & 36.67 & 121.67 & 120.67 & 298.78 & 296.20 \\
\hline Ascorbic acid & 250 & 41.33 & 38.00 & 131.33 & 126.67 & 302.88 & 298.78 \\
\hline Ascorbic acid & 500 & 47.33 & 38.00 & 144.67 & 134.00 & 308.35 & 302.89 \\
\hline Ascorbic acid & 1000 & 43.83 & 42.00 & 145.67 & 141.67 & 326.55 & 308.35 \\
\hline Gibberelic acid & 250 & 52.50 & 46.56 & 157.67 & 149.00 & 366.00 & 342.49 \\
\hline Gibberelic acid & 500 & 58.66 & 49.80 & 161.67 & 158.67 & 378.00 & 366.05 \\
\hline Gibberelic acid & 1000 & 58.90 & 52.67 & 165.55 & 177.67 & 381.00 & 372.80 \\
\hline Salicylic acid & 200 & 47.33 & 41.13 & 145.30 & 136.67 & 340.49 & 313.23 \\
\hline Salicylic acid & 400 & 50.03 & 48.67 & 143.33 & 147.33 & 342.45 & 317.13 \\
\hline Salicylic acid & 600 & 50.00 & 44.67 & 155.00 & 151.33 & 382.33 & 366.35 \\
\hline New LSD at $5 \%$ & & 5.12 & 4.93 & 17.72 & 17.17 & 35.11 & 40.2 \\
\hline
\end{tabular}

\section{2- Fruit cracking \%:}

Data illustrated in Table (2) clearly show that treating the trees with $\mathrm{GA}_{3}$, ascorbic acid and salicylic acid significantly reduced fruit cracking percentage compared to control. There were significant differences among all the

treatments. The application of $\mathrm{GA}_{3}$ at $1000 \mathrm{ppm}$ resulted in the lowest cracked fruits (1.23 and $1.27 \%)$, meanwhile control resulted in the highest cracked fruits $(3.23,3.27)$. in both seasons, respectively.

Table 2. Effect of spraying application with $\mathbf{G A}_{3}$, Ascorbic acid and Salicylic acid on grain weight \%, Fruit cracking $\%$ and rind weight $\%$ of Manfalouty pomegranate during 2005 season.

\begin{tabular}{|c|c|c|c|c|c|c|c|}
\hline \multirow{2}{*}{ Treatments } & \multirow{2}{*}{$\begin{array}{l}\text { Conc. } \\
\text { (ppm) }\end{array}$} & \multicolumn{2}{|c|}{ grain weight $(\%)$} & \multicolumn{2}{|c|}{ Fruit cracking (\%) } & \multicolumn{2}{|c|}{ rind weight $(\%)$} \\
\hline & & 2016 & 2017 & 2016 & 2017 & 2016 & 2017 \\
\hline Control & - & 52.6 & 49.47 & 3.23 & 3.27 & 39.16 & 40.20 \\
\hline Ascorbic acid & 250 & 53.33 & 51.73 & 2.43 & 2.43 & 42.10 & 41.33 \\
\hline Ascorbic acid & 500 & 53.67 & 54.73 & 3.00 & 3.07 & 42.10 & 41.66 \\
\hline Ascorbic acid & 1000 & 56.60 & 55.27 & 2.36 & 2.23 & 42.76 & 44.73 \\
\hline Gibberelic acid & 250 & 56.85 & 56.33 & 1.70 & 1.50 & 43.46 & 45.26 \\
\hline Gibberelic acid & 500 & 57.10 & 57.57 & 1.30 & 1.33 & 45.23 & 50.53 \\
\hline Gibberelic acid & 1000 & 58.90 & 58.70 & 1.23 & 1.27 & 46.66 & 57.76 \\
\hline Salicylic acid & 200 & 56.53 & 54.80 & 2.36 & 2.23 & 42.20 & 43.6 \\
\hline Salicylic acid & 400 & 56.07 & 56.04 & 2.21 & 2.17 & 42.93 & 43.93 \\
\hline Salicylic acid & 600 & 56.90 & 56.4 & 2.05 & 2.10 & 46.33 & 48.26 \\
\hline New LSD at 5\% & & 2.91 & 3.34 & 0.84 & 0.71 & 2.83 & 3.21 \\
\hline
\end{tabular}

\section{3- Fruit quality:}

Data in Table (1,2 and 3) indicate that treating the trees with $\mathrm{GA}_{3}$, ascorbic acid and salicylic acid significantly improved both physical and chemical characteristics of the fruit. The highest values in grain weight $\%$, rind weight, T.S.S, and T.S.S/acid ratio, and the lowest values in acidity $\%$ were recorded in application of the highest rate of $\mathrm{GA}_{3}$. The opposite was true for values obtained from control in both seasons.

Table 3. Effect of spraying application with $\mathrm{GA}_{3}$, ascorbic acid and salicylic acid on chemical fruit properties of Manfalouty pomegranate during 2005 season.

\begin{tabular}{|c|c|c|c|c|c|c|c|}
\hline \multirow{2}{*}{ Treatments } & \multirow{2}{*}{$\begin{array}{l}\text { Conc. } \\
\text { (ppm) }\end{array}$} & \multicolumn{2}{|c|}{ TSS } & \multicolumn{2}{|c|}{ Acidity \% } & \multicolumn{2}{|c|}{ TSS/Acid ratio } \\
\hline & & 2016 & 2017 & 2016 & 2017 & 2016 & 2017 \\
\hline Control & - & 12.63 & 13.33 & 1.63 & 1.30 & 7.87 & 10.40 \\
\hline Ascorbic acid & 250 & 13.60 & 13.93 & 1.33 & 1.29 & 10.22 & 10.79 \\
\hline Ascorbic acid & 500 & 13.75 & 14.00 & 1.28 & 1.26 & 10.74 & 11.11 \\
\hline Ascorbic acid & 1000 & 13.55 & 14.03 & 1.22 & 1.17 & 11.10 & 11.90 \\
\hline Gibberelic acid & 250 & 14.33 & 14.17 & 1.27 & 1.13 & 11.28 & 12.53 \\
\hline Gibberelic acid & 500 & 15.66 & 14.37 & 1.17 & 1.09 & 13.38 & 13.18 \\
\hline Gibberelic acid & 1000 & 15.84 & 14.53 & 1.11 & 1.04 & 14.27 & 13.97 \\
\hline Salicylic acid & 200 & 13.66 & 13.97 & 1.32 & 1.24 & 10.34 & 11.26 \\
\hline Salicylic acid & 400 & 13.81 & 14.10 & 1.28 & 1.18 & 10.78 & 11.94 \\
\hline Salicylic acid & 600 & 13.76 & 14.27 & 1.21 & 1.04 & 11.37 & 13.72 \\
\hline New LSD at 5\% & & 0.45 & 0.38 & 0.08 & 0.07 & 1.63 & 1.57 \\
\hline
\end{tabular}


Efficiency of foliar applications of elicitors on pomegranate aphid, $A$. punicae

Foliar application of ASA, $\mathrm{GA}_{3}$ and $\mathrm{SA}$ on the pomegranate aphid under field conditions resulted in significant reduction of aphid populations (Figure 1 and 2).

Reduction Percentage of aphids was increased as the concentrations of ASA, $\mathrm{GA}_{3}$ and SA increased (Figures 1 and 2) after treatment at periods of 3, 6, 9 and 12 days, but no significant difference was recorded among them after one day of treatment in both seasons. Foliar spray of 600 ppm SA gave the higher average reduction efficiency in population of pomegranate aphid compared to other elicitors in the both seasons. On the other hand, the ASA
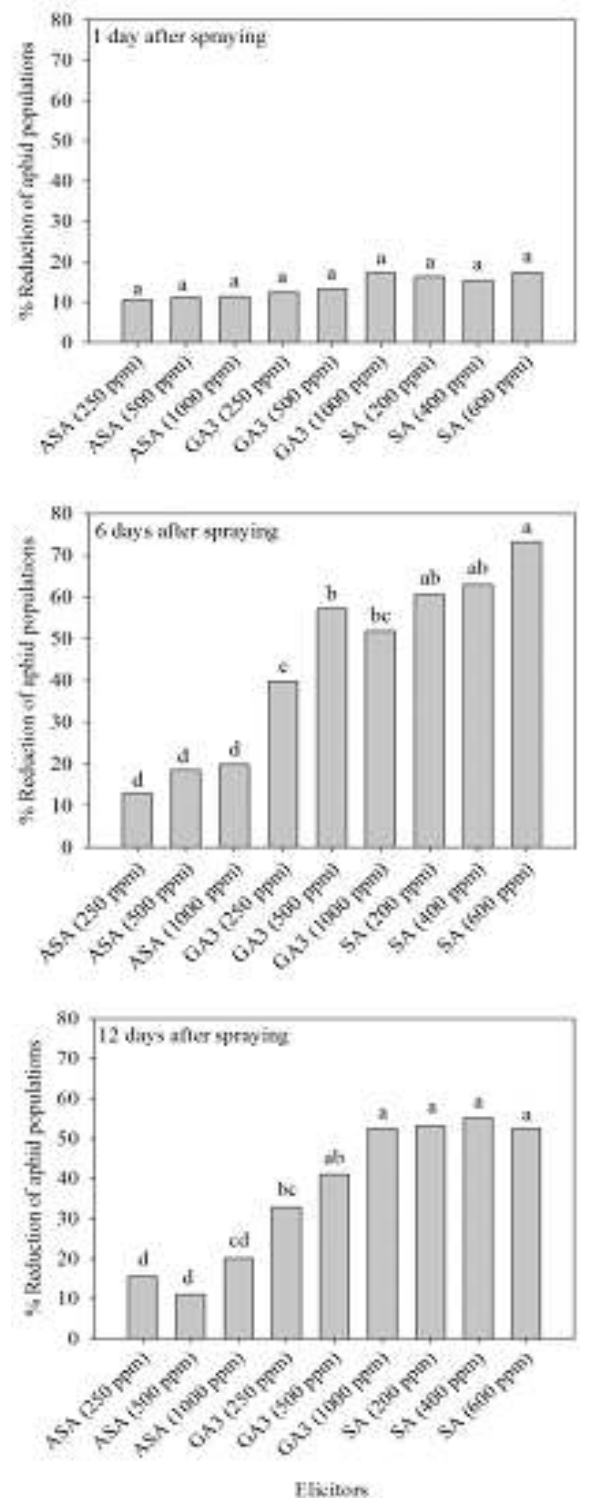

treatments had lower effect on reduction of aphid population. Our result showed that no difference between the 200 and 400 ppm SA and 1000 ppm GA $\mathrm{GA}_{3}$ treatments in both seasons. SA induced with $600 \mathrm{ppm}$ a maximum reduction in aphid population, $75.21 \%(\mathrm{~F}=24.87, P=$ $<.0001)$ and $78.97 \%(\mathrm{~F}=12.76, P=<.0001)$ at 9 day after spraying in first and second season, respectively. Spray of $4 \mathrm{mM}$ SA caused average reduction of aphid population of about $52.25 \%(\mathrm{~F}=21.35, P=<.0001)$ and $56.80 \%(\mathrm{~F}=$ $24.10, P=<.0001)$ in first and second seasons, respectively. The results clearly exhibit the effectiveness of the elicitors against pomegranate aphids.
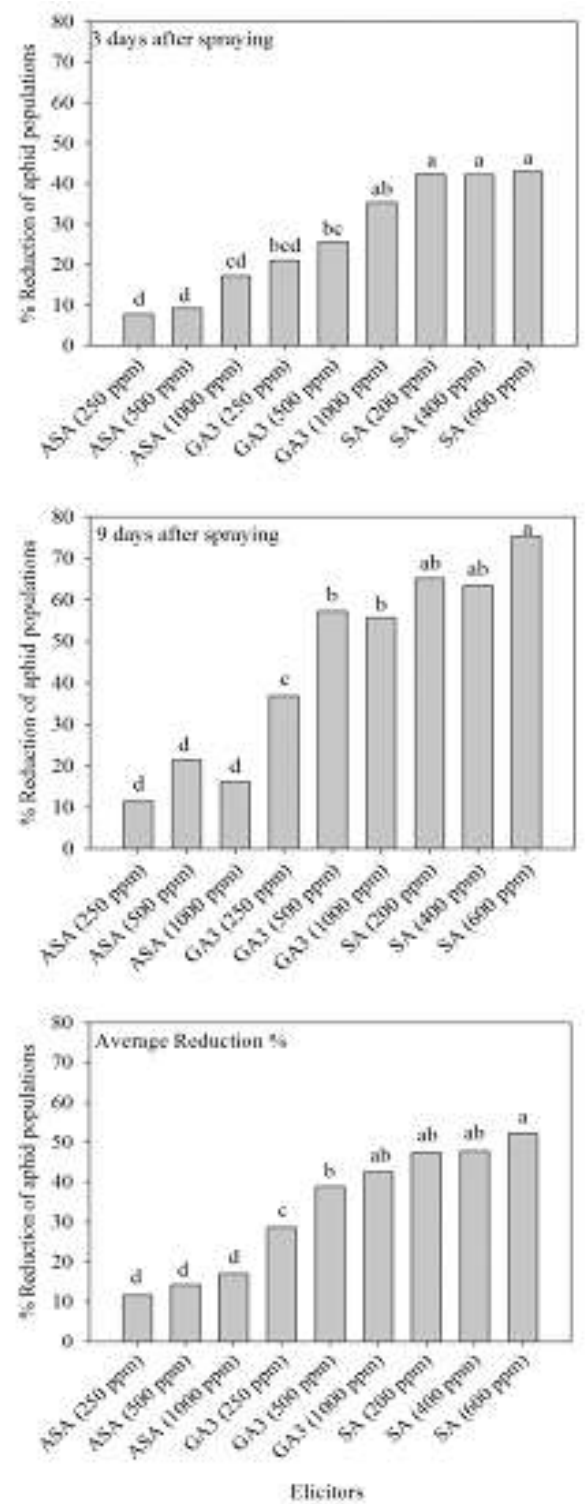

Fig. 1.Efficacy of foliar applications of elicitors on pomegranate aphid, A. punicae under field condition at 1, 3, 6, 9 and 12 day after treatments in 2017 season. ASA: Ascorbic acid, GA $\mathbf{A}_{3}$ : Giberellic acid, SA: Salicylic acid. Columns headed by different letter(s), within the same treatment date, are significantly different $(P \leq 0.05)$ according to New LSD Test. 

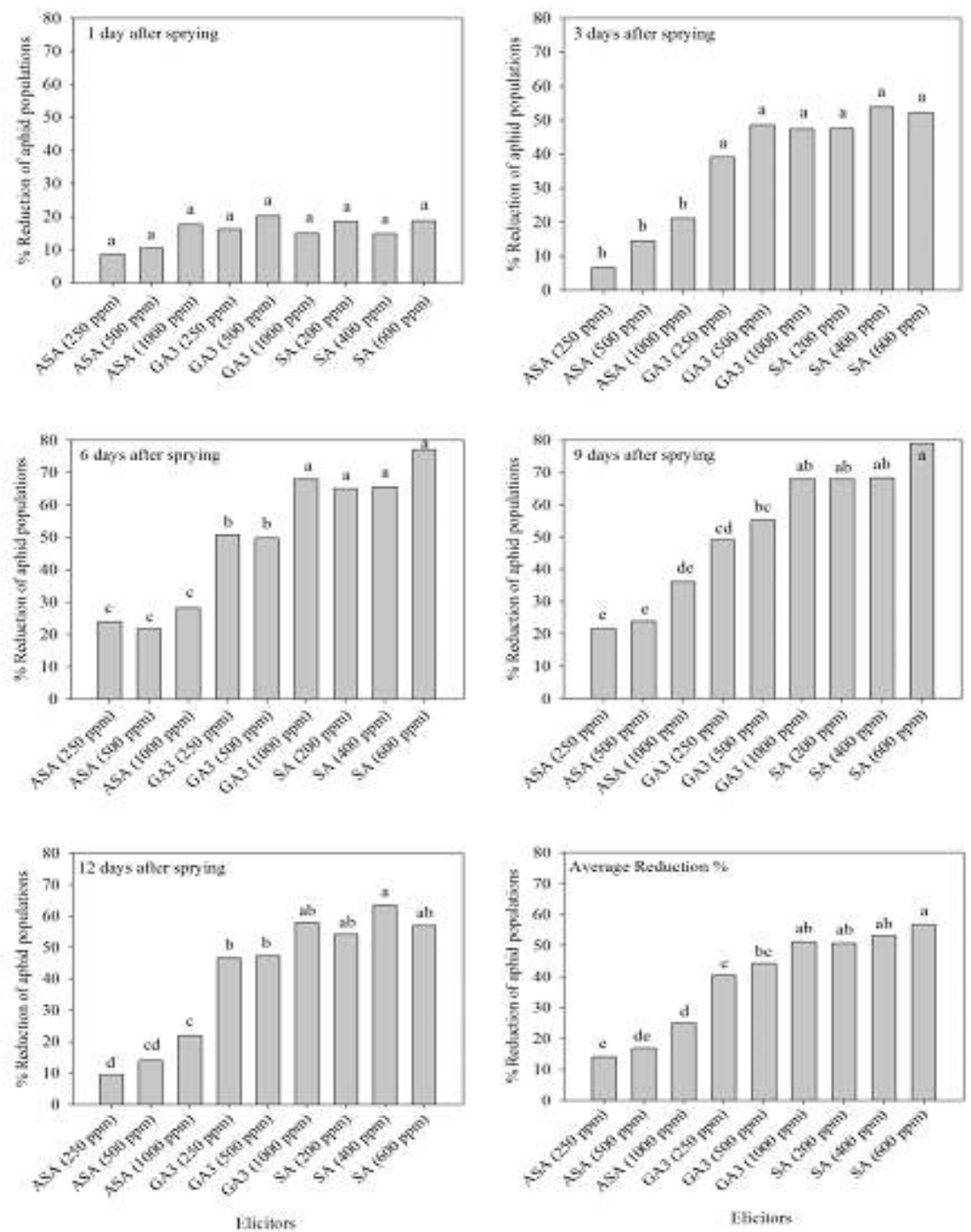

Fig. 2.Efficacy of foliar applications of elicitors on pomegranate aphid, A. punicae under field condition at 1, 3, 6, 9 and 12 day after treatments in 2018 season. ASA: Ascorbic acid, GA3: Giberellic acid, SA: Salicylic acid.Columns headed by different letter(s), within the same treatment date, are significantly different $(P \leq$ 0.05) according to New LSD Test.

\section{Discussion}

The results from this study clearly showed that tested elicitors affected growth of pomegranate trees, and subsequently influenced the performance of the pomegranate aphids. Our data showed that foliar application of ASA, $\mathrm{GA}_{3}$ and $\mathrm{SA}$ on pomegranate trees significantly improved plant growth, quantity and quality of fruits.

When phytohormones are applied, the plant undergoes changes in carbohydrate and amino acids in leaves (Khodary 2004; Liang et al. 2006; Chandra et al. 2007; Tytgat et al. 2013), but less is known about phytohormone induced changes in the phloem sap composition. Spraying gebrillic acid enhanced total yield, TSS and reduced cracking fruits and acidity (Sharifi and Sepahi 1984, Ghosh et al. 2009, Y1lmaz and Özgüven 2009, Shanmugasundaram, and Balakrishnamurthy 2017).
In pomegranates, application of SA enhanced total and marketable yield, fruit weight and diameter, TSS, and reduced acidity and fruit cracking (Abdel Aziz et al. 2017). In pomegranates, application of SA enhanced total and marketable yield, fruit weight and diameter, TSS, and reduced acidity and fruit cracking (Abdel Aziz et al 2017).

Application of salicylic acid, also, increased total yield, number of fruit/plant, fruit weight and TSS and decreased titratable acidity in Mango (Ngullie et al. 2014), grape (El-kenawy 2017) and strawberry (Mohamed et al. 2017; Qureshi et al. 2013). Application of ASA increased total and marketable yield, fruit weight and diameter, TSS, and reduced acidity and fruit cracking. Application of salicylic acid, also, increased total yield, number of fruit/plant, fruit weight and TSS and decreased acidity in orange (El-Badawy et al. 2017).

Pomegranate growth and development depends largely as any other plant on phyto-hormones, which 
control metabolic processes and tolerance to biotic and abiotic stresses. These hormones play a vital role in the plant signalling in the processes of biosynthesis of metabolites that contribute to vegetative and reproduction stages and the plant response to biotic and abiotic stress.

Gibberellic acid is a plant hormone that stimulates plant growth, transitions from meristem to shoot growth and vegetative to flowering, and promotes grain development and cells elongation (Gupta and Chakrabarty 2013). $\mathrm{GA}_{3}$ works in concert with auxins. Meanwhile, auxins increases the plasticity of cell wall, $\mathrm{GA}_{3}$ elongates the cells. Thus, cell could be enlarged and gain weight. Salicylic acid as growth hormone influences seed germination, seedling establishment, cell growth, photosynthesis, heat tolerance, nutrient uptake and fruit yield. The effect of SA on some of these biological processes may be indirect because SA manipulates the effect of other plant hormones (Yusuf et al 2013). The application of SA increases fruit weight, total sugars and these observations could be attributed to the increase of photosynthesis pigments, transporting sugars and root length in plants (Hayat et al. 2005, Ahmed et al. 2013 and Larqué and Martin (2007).

Ascorbic acid is one of the major components of antioxidation system during environmental stress. ASA plays role in photo protection of photosynthesis apparatus and cell division and expansion (Smirnoff 1996).

Our results showed that the aphid populations were lower in the treated trees than in the untreated trees with $\mathrm{SA}$ is the most effective treatment in aphid population reduction. These observations may be attributed to elicitors' application that deterred aphids from pomegranate and increased foraging by parasitoids and predators attacking herbivorous insects of pomegranate tree. Application of SA induces systemic defense and significantly decrease aphid population in wheat (Mahmoud and Mahfouz 2015) and in tomatoes (Goggin, 2005). In pecan, the foliar application of $\mathrm{GA}_{3}$ mitigated the injury occurred by black aphid (Hemiptera: Aphididae) (Cottrell et al. 2010).

Elicitors such as $\mathrm{GA}_{3}$ and $\mathrm{SA}$ are important signals in the plant response against insect-herbivore, including the production of proteinase inhibitors, toxic secondary metabolites, and the production and release of volatile organic compounds (VOC). They regulate induced defense mechanisms in plants after insect attack and wounding. Most of the salicylate induced proteins (JIPs) (Vandenborre et al. 2009) have direct defense function against insects. SA has been reported to induce defense enzymes (War et al. 2011a; Noreen and Ashraf, 2009). Significant increase in polyphenol oxidase (PPO) activity in wheat was observed with application of SA (Pokhare et al. 2012). Exogenous application of SA at $1.5 \mathrm{mM}$ induced higher (PPO) activity in chickpea (Cicer arietinum L.) leaves (War et al. 2011b). Pathogenesis-related (PR) proteins are involved in plant defense against insects and multiple signaling pathways that SA regulate their induction (War et al. 2012).

In conclusion, $\mathrm{SA}$ and $\mathrm{GA}_{3}$ were effective in reducing of aphid population and improving plant growth and fruit quality in pomegranate. Further investigation is needed to elucidate the mechanism underlay these effects.

\section{REFERENCES}

Abdel Aziz, F.H.; M.A. El-Sayed and H.A. Aly (2017). Response of Manfalouty Pomegranate Trees to Foliar Application of Salicylic Acid Acid. Assiut J. Agric. Sci., 48 (2): 59-74

Ahmed, S.; Z. Sengh; A. Sattar Khan and Z. Iqbal (2013). Pre-harvest applicaton of salicylic acid maintain the rind textural properties and reduce fruit rot and chilling injury of sweet orange during cold storage, Pak. J. Agri. Sci., 50 (4): 559-569.

Chandra, A.; A. Anand and A. Dubey (2007). Effect of salicylic acid on morphological and biochemical attributes in cowpea. Journal of Environmental Biology 28, 193-196.

Cottrell, T.E.; B.W. Wood and X. Ni (2010). Application of plant growth regulators mitigates chlorotic foliar injury by the black pecan aphid (Hemiptera: Aphididae). Pest Management Science. 66:12361242.

Davidson, M.H.; K.C. Maki; M.R. Dicklin; S.B. Feinstein; M. Witchger; M. Bell; D.K. McGuire; J.C. Provost; H. Liker and M. Aviram (2009). Effects of consumption of pomegranate juice on carotid intima-media thickness in men and women at moderate risk for coronary heart disease, Am. J. Cardiol., Vol. 104, No. 7, pp.936-942.

El-Badawy, H.E.M.; S.F. El-Gioushy; M.H.M. Baiea and A.A. El-Khwaga (2017). Impact of Citric Acid, Ascorbic Acid and Some Nutrients (Folifert, Potaqueen) on Fruit Yield and Quality of Washington Navel Orange Trees. Asian Journal of Advances in Agricultural Research 4(3): 1-13

El-Kenawy, M.A. (2017). Effect of Chitosan, Salicylic Acid and Fulvic Acid on Vegetative Growth, Yield and Fruit Quality of Thompson Seedless Grapevines Egypt. J. Hort. Vol. 44, No. 1, pp. $45-$ 59

Elwan, M.W.M.; M.A.M. El-Hamahmy (2009). Improved productivity and quality associated with salicylic acid application in greenhouse pepper. SciHortic.122:521-6.

Ghosh, S.N.; B. Bera; S. Roy and A. Kundu (2009). Effect of plant growth regulators in yield and fruit quality in pomegranate cv. Ruby 1, J. Hortl. Sci. 4 (2): 158160

Goggin, F.L. (2005). Divergent defensive pathways in tomato, and their effects on plant-aphid interactions .Abstracts / Comp. Biochem.Phys. A, 141: S225S236.

Goggin, F.L. (2007). Plant-aphid interactions: molecular and ecological perspectives.- Current Opinion in Plant Biology, 10: 399-408.

Gupta, R. and S.K. Chakrabarty (2013). Gibberellic acid in plant still a mystery unresolved plant. Signal behav 1; 8(9): e25504.

Hayat, Q.; S. Hayat; M. Irfan; A. Ahmad (2010). Effect of exogenous salicylic acid under changing environment: a review. Environ Exp Bot 68:14-25.

Hayat, S.; Q. Fariduddin; B. Ali and A. Ahmad (2005). Effect of salicylic acid on growth and enzyme activities of wheat seedlings. Acta. Agronomica Hungarica. 53: 433-437.

Henderson, C.F. and E. W. Tilton (1955). Tests with acaricides against the brow wheat mite, J. Econ. Entomol. 48:157-161.

Khodary, S.E.A. (2004). Effect of salicylic acid on the growth, photosynthesis and carbohydrate metabolism in salt stressed maize plants. International Journal of Agriculture and Biology 6, 5-8. 
Kondo, S. (2006). The roles of jasmonates in fruit color development and chilling injury. Acta Hortic. 727, 45-56

Larqué-Saavedra, A. and R. Martin-Mex (2007). Salicylic acid and bioproductivity c.f.Hayat, S., and A. Ahmad (edts). Salicylic Acid a Plant Hormone. Chapter 2 Springer.

Liang, Y.S.; Y.H. Choi; H.K. Kim; H.J.M. Linthorst and R. Verpoorte (2006). Metabolomic analysis of methyl jasmonate treated Brassica rapa leaves by 2dimensional NMR spectroscopy. Phytochemistry 67, 2503-2511.

Mahmoud, F.M. and H.M. Mahfouz (2015).Effects of salicylic acid elicitor against aphids on wheat and detection of infestation using infrared thermal imaging technique in Ismailia, Egypt. Pestic Phytomed, 30(2): 91-97

Marzouk, H.A.; HA. Kassem (2011). Improving yield, quality, and shelf life of Thompson seedless grapevine by preharvest foliar applications .SciHortic . $130: 425-30$.

Mohamed, R.A.; A. Al-Kharpotly and D.Y Abd-Elkader (2017). Salicylic Acid Effects on Growth, Yield, and Fruit Quality of Strawberry Cultivars. Journal of Medicinally Active Plants6, (2):1-11.

Ngullie, C.R.; R.V. Tank and D.R. Bhanderi (2014). Effect of salicylic acid and humic acid on flowering, fruiting, yield and quality of mango (Mangiferaindica L.) cv. KESAR. Adv. Res. J. Crop Improv, 5 (2): 136-139.

Noreen, Z. and M. Ashraf (2009). Change in antioxidant enzymes and some key metabolites in some genetically diverse cultivars of radish (RaphanussativusL.). Envi-ron. Exp Bot., 67: 395402

Pokhare, S.; N.A. Shakil; J. Kumar and K. Singh (2012). Foliar application of chemical elicitors induces biochemical changes in wheat against the cereal cyst nematode, Heteroderaavenae. Nematolmedit, 40: $181-187$

Qureshi, K.M.; S. Chughtai; U.S. Qureshi and N.A. Abbasi (2013). Impact of exogenous application of salt and growth regulators on growth and yield of strawberry. Pak. j. bot., 45(4): 1179-1185.

Raskin, I. 1992. Role of salicylic acid in plants. Ann. Rev. Plant Physiol. Plant Mol. Bio.1, 43: 439-463.

Sarkhosh, A.; Z. Zamani; R. Fatahi; H. Ghorbani and J. Hadian (2007). A review on medicinal characteristics of pomegranate (Punica granatum L.). Journal of Medicinal Plants, 6(22): 13-24.

Shanmugasundaram, T. and G. Balakrishnamurthy (2017). Exploitation of Plant Growth Substances for Improving the Yield and Quality of Pomegranate under Ultra High Density Planting. Int. J. Curr. Microbiol. App. Sci. 6(3): 102-109
Sharifi, H. and A. Sepahi. (1984). Effect of Gebbrillic on fruit cracking in Meykhosh pomegranate. Iran agricultural research, 3(2): 149-155

Smirnoff, N. 1996. The Function and Metabolism of Ascorbic Acid in Plants .Annals of Botany 78: 661-669

Smith C.M.; E.V. Boyko (2007). The molecular bases of plant resistance and defense responses to aphid feeding: current status.- Entomologia Experimentalis et Applicata, 122: 1-16.

Stover, E. and E.W. Mercure (2007). The pomegranate: A new look at the fruit of paradise. HortScience, 42: 1088-1092.

Tytgat, T.O.; K.J.F. Verhoeven; J.J. Jansen; C.E. Raaijmakers; T. Bakx-Schotman; L.M., McIntyre; N.M. van Dam (2013). Plants know where it hurts: root and shoot jasmonic acid induction elicit differential responses in Brassica oleracea. PLOS ONE 8, e67726.

Vandenborre, G.; O. Miersch; B. Hause; G. Smagghe; C. Wasternack and E.J.M. Van Damme (2009). Spodoptera littoralis induced lectin expression in tobac-co. Plant Cell Physiol, 50: 1142-1155

Walling, L.L. (2008). Avoiding effective defenses: strategies employed by phloem-feeding insects.Plant Physiology, 146: 859-866.

War, A.R., Paulraj, M.G., Ahmad, T., Buhroo, A.A., Hussain, B., Ignacimuthu, S. and Sharma, H.C. (2012). Mechanisms of plant defense against insect herbivores. Plant Signal Behav, 7(10): 1306-1320.

War, A.R.; M.G. Paulraj; M.Y. War and S. Ignacimuthu (2011a). Jasmonic acid- mediated induced resistance in groundnut (Arachis hypogaea L.) against Helicoverpa armigera (Hubner) (Lepidoptera: Noctuidae). J. Plant Growth Regul.,30: 512-523

War, A.R.; M.G. Paulraj; M.Y. War and S. Ignacimuthu (2011b). Role of salicylic acid in induction of plant defense system in chickpea ( CicerarietinumL .) .Plant Signal Behav., 6: 1787-1792

Y1lmaz, C. and A.I. Özgüven (2009). The effects of some plant nutrients, gibberellic acid and pinolene treatments on the yield, fruit quality and cracking in pomegranate. Acta horticulturae (818): 205-212

Yusuf, M.; S. Hayat; M.N. Alyemeni; Q. Fariduddin and A. Ahmad (2013). Salicylic Acid: Physiological Roles in Plants. In S. Hayat et al. (eds.), Salicylic Acid.Springer Science+Business Media Dordrecht.

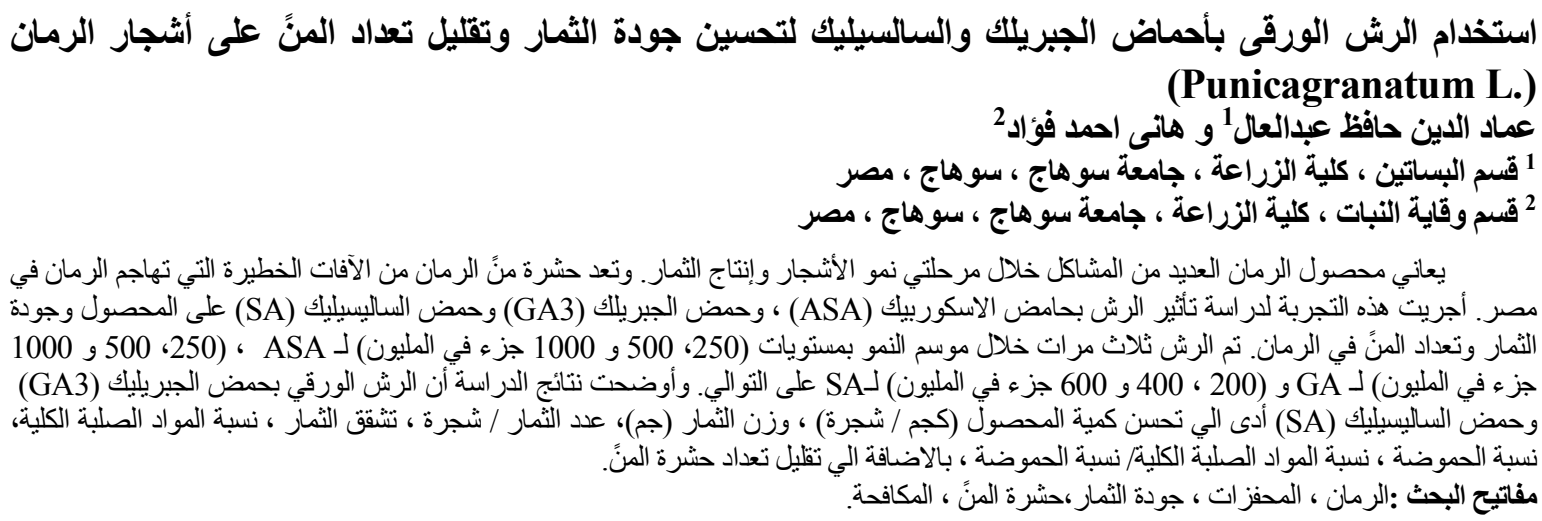

